\title{
The performance of the European Union in the International Labour Organization
}

\author{
Dr Robert Kissack \\ Institut Barcelona d'Estudis Internacionals \\ rkissack@ibei.org
}

June 2011

\begin{abstract}
:
This article examines EU performance by assessing its effectiveness in the ILO and the relevance of the EU to its major stakeholders between 1992-2010. Making a distinction between technical and political domains, it maps the ILO policy-making structures in which the EU must operate. In the technical domain it argues that although the EU has been effective in uploading its policy preferences into ILO labour standards, the relevance of collective EU representation to the member states has marginally decreased since 1992 by comparison to the previous 20 years. In the political domain there has been considerable progress enhancing EU performance in promoting compliance with labour standards within the ILO's monitoring system, although the increase results from higher relevance than greater effectiveness. It also argues that the institutional environment of the ILO, constituted by its rules, norms and practices, play an important role in assessing EU performance. Doing so calls into question established assumptions about EU behaviour in international organisations.
\end{abstract}




\section{Introduction}

This article analyses the performance of the European Union (EU) in the International Labour Organization (ILO), the United Nations (UN) specialised agency promoting decent work and labour rights. It forms part of a larger research project undertaking a comparative assessment of EU performance across a range of international institutions. ${ }^{1}$ The time frame studied is 1992 to 2010, capturing the emergence of the European Union as an international actor, as well as a period of great change for the ILO. The end of the Cold War brought the existence of the ILO into question (Maupain 2005: 85). Although by no means its exclusive function, since 1919 Western liberal capitalist states saw it as an important counterweight to the appeal of socialist revolutions and communism. Throughout the Cold War, the West used the ILO to denounce communist countries claiming to represent the interests of workers while preventing their free association through labour unions. Any assessment of EU performance must be situated in the broader context of the ILO seeking to define its role in the rapidly changing architecture of global governance.

EU-ILO relations are highly complex and the literature usually focuses on particular aspects, for example trade and development policy (Orbie \& Babarinde 2008), General System of Preferences (GSP) trade agreements and ILO labour standards (Orbie and Tortell, 2009a, 2009b), the legal aspects of EUILO relations (Cavicchiolo 2002; Novitz 2005, 2008, 2009), EU coordination (Nedergaard 2009; Kissack 2008; Riddervold 2008, 2009), or EU participation in standard setting (Delarue 2006; Tortell et al 2009; Kissack 2009b, 2009c, 2010). This article explores EU performance cutting across these issue areas. It begins by defining performance as effectiveness and relevance, after which it provides empirical evidence of how the EU has behaved over the last two decades and what this tells us about EU performance. ${ }^{2}$ Throughout the article a distinction is

\footnotetext{
${ }^{1}$ European Science Foundation Application 09-ECRP-015: EU Performance in the ILO, funded by Spanish Ministry of Education and Science.

2 This article is informed by numerous interviews with officials from EU member states, the ILO and EU over a number of years, most recently in Brussels 23-24 May 2011.
} 
made between technical and political domains, following Johnson's claim that the 'EU acts most effectively as a group on political issues, has a mixed record on technical issues, and is weakest on budgetary matters' (Johnson 2005: 144). In this regard, 'technical' refers to the process of drafting labour standards, while 'political' refers to the process of scrutinising their state adherence to labour standards. Given constraints on space, only the first and second propositions are demonstrated to be accurate. In the technical domain EU performance is a function of both effectiveness and relevance, but there has been relatively little change over time compared to the previous 20 years (1973-1992). In the political domain EU performance has increased overtime, albeit from a low level, due to increased relevance of the EU to its primary stakeholders (member states). More specifically, it highlights that in both domains the institutional environment (formal and informal) is extremely important in determining the parameters in which the EU must perform, and must always be taken into consideration.

\section{Theorising EU performance in the ILO}

EU performance is measured primarily in two dimensions: effectiveness and relevance. 'Effectiveness' is defined as the extent to which EU goals are successfully uploaded into ILO decision making processes and therefore accepted as ILO goals. 'Relevance' is defined as the extent to which EU actors (or 'stakeholders') choose to use EU institutions as their preferred mechanism of engagement with the ILO. In this article, the EU is defined as the member states and the institutions of the Union, although the majority of the analysis focuses on the former as legal members of the ILO. The European Commission plays a secondary role, either by representing the European Community (EU postLisbon) in its official relations with the ILO, or by assisting in the coordination of EU member states' common representation of the EU in the ILO. This relationship is based on an exchange of letters between European Commission 
and the ILO in May 2001 and a Memorandum of Understanding signed in 2004. ${ }^{3}$ The European Parliament (EP), the European Court of Justice (ECJ) and the European Economic and Social Committee (EESC) are additional stakeholders, as are European federations of workers and employers. The ILO is unique among international organisations insofar as non-governmental actors are fully integrated into the legislative and executive apparatus. Workers and employers representatives enjoy autonomy in the ILO's tripartite structure, while also being an integral part of national representation (each ILO member sends two government, one worker and one employer representative to the annual conference). In order to operationalise effectiveness and relevance, this section describes the policy-making process in the ILO, the goals of the EU and the relevance of the EU to its stakeholders.

\subsection{Policy making processes}

Since performance is a function of effectiveness, and effectiveness is a result of an actor's capacity to exert influence at significant stages of the policy-making process, we begin with an exploration of the policy-making processes in the ILO in both the technical and political domains. From this follows an assessment of (a) how each stage impacts on the final policy outcome, (b) how the EU can maximise its influence in the most important stages of the policy-making process and (c) whether the EU coordinates participation in each stage.

\section{Technical}

There are six stages in the policy-making process leading to the adoption of a recommendation and/or convention in the annual International Labour Conference (ILC), the legislative assembly of the ILO. The first is a decision taken in the Governing Body (GB - the ILO's 56-member executive council that convenes tri-annually and is composed of 28 governments, 14 workers and 14

\footnotetext{
${ }^{3}$ http://ec.europa.eu/europeaid/what/socialprotection/documents/memorandum of understanding ec ilo en.pdf (Accessed 5 June 2011).
} 
employers) to place the drafting of a new instrument on the agenda of a forthcoming conference, clearly locating agenda setting power with the GB members. EU participation in the GB consists of four permanent government members (France, Germany, Italy and the UK) and three elected members (currently Austria, Poland and the Czech Republic for 2008-11), and trade unionists and employers' federations from EU member states. There is no formal EU coordination at this level but the European Commission is active in working groups focused on the Social Dimension of Globalisation. The second stage establishes a technical meeting of experts to discuss the contents of the new instrument. Based on their report, the ILO secretariat circulates a draft text and questionnaire to ILO members for tripartite consultation at the national level. The second stage serves to define the scope of the instrument, and the third allows members to petition for their national preferences, but neither directly shapes the final output. There is no formal EU coordination in either stage, although in 1994 the European Commission proposed returning questionnaires via Brussels, something rejected by the Council and the EESC (EC 1994, EESC 1995).

The fourth stage is an ILC committee meeting to discuss the ILO secretariat's draft text based on questionnaire responses. The tripartite constituents bargain over the type of instrument (convention, recommendation or protocol), its scope and ambition, but for the majority of instruments a second committee meeting is convened the following year to finalise the text. Therefore the fourth stage, while important, cannot concretely determine the final policy output. The drafting committee meeting held the following year to negotiate the final text constitutes the fifth stage and is the most important stage of the process; ILO members devote the majority of their resources to preparing for this committee, and decisions are taken by consensus when possible, but by simple majority (using a weighted voting system to give workers, employers and governments equal representation) when necessary. Once the text is finalised it is presented to the conference plenary for adoption (sixth stage). The vote, by simple majority (requiring a two-thirds quorum) is to accept or reject the 
instrument, and can neither request revisions by the drafting committee nor change its content. When the plenary fails to adopt an instrument it is simply that: a failure. ${ }^{4}$ Seen from this perspective, the fifth stage of the policy-making process is more important than the sixth because it creates the final text. EU coordination often takes place in stages four and five, although there have been a significant number of cases of non-cohesive voting between EU member states in stage six.

\section{Political}

All governments, including EU member states, have much less influence in the process for supervising adherence to conventions, with workers and employers enjoying agenda setting power. The supervision process begins with an independent group of 20 legal experts sitting on the Committee of Experts on the Application of Conventions and Recommendations (CEACR) scrutinising ILO member governments' compliance with the conventions they have ratified, and compiled into an annual report. ${ }^{5}$ Workers' and employers' representatives choose 25 cases from that report to discuss in the Committee on the Application of Standards (CAS), convened annually at conference and open to all ILO members. Case selection seeks to ensure regional balance and consequently EU member states are frequently included. The committee invites these governments to defend their actions and hears statements from other ILO members, including interventions by the EU Presidency. A report is adopted by the committee at the end of its hearing and presented to the plenary without a vote. Often CAS reports contain 'special paragraphs' drawing attention to the most serious cases identified by workers and employers that deserve additional naming and shaming. Despite being defined as political because it allows states to comment on the domestic affairs of other states, the integrity of the scrutiny

\footnotetext{
${ }^{4}$ This explains why instruments are so seldom rejected; in the last 40 years, only one instrument (the 2005 convention on the Fishing Industry) was rejected, and that was by one vote out of a total of 436.

${ }^{5}$ http://www.ilo.org/global/standards/applying-and-promoting-international-labourstandards/committee-of-experts-on-the-application-of-conventions-andrecommendations/lang--en/index.htm (accessed 3 January 2011)
} 
process is maintained through preventing it becoming politicised by government members.

\section{$2.2 \quad$ Goals}

What does the EU want to achieve through its engagement with the ILO? Listed below are four core goals that constitute the EU's strategic ambition, the first two located in the technical domain and the latter in the political domain. While not exhaustive, they nonetheless capture the central tenets of what the EU wants from its relation with the ILO.

Promotion of the Decent Work Agenda. An articulated EU goal since 2001, it entails assisting the ILO in maximising welfare and employment standards globally (EC 2001, 2004, 2006, 2008; EESC 2007; EU Council 2007: 14).

Promoting the European Social Model. Novitz argues that the EU promotes its own interpretation of ILO fundamental labour standards, 'predominantly a civil liberties, market-led agenda ... rather than socio-economic rights to collective bargaining which are compromised within a market order' (Novitz 2008: 149).

Upholding international labour standards. Like all ILO members, the EU seeks to ensure that all governments adhere to the labour standards they have ratified, by supporting the ILO's independent experts that scrutinise members' domestic practices to provide transparency, highlighting when states violate ratified conventions (Orbie \& Tortell 2009b).

Ensuring Consistency with CFSP Common Positions. The EU expresses CFSP common positions through demarches on a wide range of issues, including human rights violations. All four core labour standards (codified in eight conventions) are already incorporated into the Universal Declaration on Human Right (UDHR), with only the convention prohibiting forced labour (C29 from 1930) predating it (Alston 2005: 2). For the EU to have a consistent CFSP, it must speak up in the ILO. 


\subsection{Dimensions of relevance}

Having already identified the relevant stakeholders in the EU-ILO relationship, how do they relate to the central category of "relevance"?

Degree of unity in the policy-making process. To what extent does the EU speak with one voice during the policy making process? This spans all stakeholders, beginning with the 27 member states and the degree to which some prioritise national preferences over EU policies. The tripartite design of the ILO means that workers and employers are fully integrated into the policymaking process at all levels, although unity between the two vis-à-vis each other, and with EU member state governments, varies greatly. Specifically, we expect divergence stratified between actors favouring social protection and actors favouring market liberalisation.

Internal Coordination of Policy. Are common EU policies the lowest common denominators between national policies, or does a common European interest exist? Does the coordination of internal policy take place in a framework of bargaining over interests as rational choice models predict, or do we find evidence of common identities, shared interests and social learning taking place, as constructivist approaches demonstrate (Riddervold 2009)? More specifically to the ILO case, how easily are policy positions agreed in Brussels transposed into the Geneva working environment? Do the national experts seconded from capitals to negotiate in Geneva have experience of EU coordination methods? The Council Secretariat drew attention to the differing practices of coordination between the 'UN cities' and Brussels and proposed strategies to overcome potential problems arising from this geographical disjuncture (EU Council 2003), and in recent years more preparatory meetings have been held in Brussels prior to the annual conference in Geneva.

Delegation to EU actors. Who speaks for the EU varies across policy areas and in different stages of the policy-making process? Since 1992, the Presidency has dominated the representation of the EU member state, breaking a trend started in the 1980s when Commission officials spoke on behalf of the member 
states in a number of technical meetings. ${ }^{6}$ Other channels of communication between the EU and the ILO include annual EC-ILO high-level meetings, and ILC speeches by the Commissioner for Social Affairs and Employment and the chair of the EESC. However, none of these are as important in influencing EU performance as the behaviour of member states.

\section{EU performance in the technical policy domain}

The relevance of the EU to its stakeholders

Since 1992, the ILO has adopted 16 conventions and 21 recommendations, predominantly regarding occupational health and safety and maritime standards, but also on child labour, maternity law, part-time and home working. In comparison to the lifetime of the organisation, the last two decades are legislatively low-key. Despite constituting 20\% of the ILO's working life, the period has contributed only $8.5 \%$ of the conventions and $10 \%$ of the recommendations on its statute. Instead of creating new standards, efforts have focused on increasing the level of ratification of existing ones, principally through the 1998 Declaration on Fundamental Rights and Principles at Work, and more recently in the consolidation of over 60 existing instruments in the Maritime Labour Convention (MLC).

As the principle stakeholders, how relevant has the EU been to its member states? In technical issues, the EU is defined as relevant to member states when they are collectively represented through the EU presidency. The most striking observation is how little progress the EU has made in its common representation in technical committees over the last two decades. Close reading of the records of proceedings published by the ILO provide an accurate picture of who spoke on behalf of the EU, how often and what was said. Looking only at the fifth stage of

\footnotetext{
${ }^{6}$ The reason for this is a 1990 dispute during the drafting of C170 over who should represent the member states when discussing technical issues related to community competency (Cavicchiolo 2002). It was only resolved through an ECJ opinion (2/91) that ruled member states must represent the European Community in areas of common competency, not the Commission.
} 
the policy making process (second drafting committees), the EU was represented (defined as interventions made in the name of the EU member states) in 12 of the 16 conventions drafted between 1992 and 2010. Three conventions should be excluded from this tally on the grounds that the interventions did not shape the content of the instrument, ${ }^{7}$ making it more accurate to say EU representation contributed to the final policy output $56 \%$ of the technical standards set over this period. ${ }^{8}$ The story is the same with the six recommendations drafted as stand-alone legal texts during the period, where EU participation contributed to the final outcome in four of them (67\%). ${ }^{9}$ In the period from 1973 to 1992, the relevance of EU coordination to its member states was very similar. Out of 34 conventions during this period, the EU was represented in 24 (of which six must be excluded on the grounds of insufficient participation to affect the policy output). Similarly, out of four recommendations drafted as stand-alone instruments, the EU was represented in three (but one must be excluded for insufficient participation). Comparing the two periods reveals that EU representation rose from $53 \%$ to $56 \%$ in conventions and from $50 \%$ to $67 \%$ in stand-alone recommendations. Indeed, if one were to look at the relevance of the EU to its member states after 1992 in the longer context of its common representation in the ILO since 1973, the more obvious research question would be to explain its stasis in recent decades (Kissack 2008).

\footnotetext{
7 The interventions - one in the case of C177 (Home work 1996) and two in the case of C185 (Seafarers Identity Documents 2003) - were made in the preliminary general discussion. In C182 (Child Labour) the EU only spoke during the first drafting meeting. In the latter two instruments, EU member states were very active in drafting negotiations as part of a larger group of IMEC states.

${ }^{8}$ The EU representation was high in instruments concerning industrial accidents (C174), safety in mining (C176), in agriculture (C184) and occupational health and safety (187), as well as regulating employment law in areas such as insolvency protection (C173) and private agencies (C181). Representation in maritime standards was inconsistent, with the EU being conspicuously absent in the 1996 maritime conference and the three conventions adopted there (C178-180) but participated in the Maritime Labour Convention of 2006 and the fishing sector convention of 2007 (revised from the failed 2005 text). For reasons why EU representation disappeared during the mid 1990s, see Kissack 2008.

${ }^{9}$ The 14 conventions had accompanying recommendations drafted at the same time and in this survey are treated as one negotiating process (C185 and MLC excluded). Of the six others, the EU made significant contributions in three concerning job creation (R189), occupational diseases (R194), protecting workers rights (R198) and HIV/AIDS in the workplace (R200).
} 
Following the progress of ILO instruments form the fifth to sixth stages in the decision making process uncovers more evidence of EU irrelevance. Since 1992 , there were 17 votes in plenary sessions (out of $38^{10}$ ) where one or more EU member state voted differently to others (either abstaining or against). ${ }^{11}$ However, 16 of these were paired conventions and recommendations drafted simultaneously so are considered as eight incidents of non-coherent EU voting. Significantly, four of the nine incidents splits took place after common EU representation in the fifth stage. ${ }^{12}$ Why do member states expend resources on coordinating a common position and delegating to the Presidency its articulation, only to splinter in the final vote? This phenomenon has plagued the EU in the ILO since the 1970s and one cause is the dilemma actors face in the ILO of reconciling antagonistic domestic and international interests. As I have argued elsewhere, Putnam's two-level game analysis explains how actors in the ILO seek to satisfy both domestic constituents and international partners when the two are in opposition. They signal to national audiences that they have defended national interests in the plenary vote (either abstaining or voting against), while in private committee meetings of the fifth stage, where real influence is wielded, they are prepared to cooperate with ILO partners and fulfil international obligations (Kissack 2009b, Kissack 2010). All actors, including EU member states, on occasion strategically free-ride on the assumption that plenary votes will be passed and take the opportunity to signal opposition to a given standard, thus accommodating disgruntled national constituents without scuppering ILO action. These cases are not cut-and-dried evidence of EU irrelevance that they appear to be, but instead demonstrate how EU member states use informal ILO norms of behaviour to reconcile seemingly opposing goals. The appraisal of

\footnotetext{
10 This figure includes the 2005 vote on a Fishing Convention which failed, and its associated recommendation (R196) that passed but has been removed from list of recommendations on the ILO website http://www.ilo.org/ilolex/english/recdisp1.htm (accessed 8 June 2011).

11 In technical votes the EU majority position has historically always been to accept the instrument. Since 1992 the UK has voted against 6 instruments (C175, C177, C179, R184, R186, R187) and abstained 7 times (C178, C180, C183, R182, R191, R198); Germany has voted against once (C177); France has abstained 3 times (C175, C178, R185); three states have abstained twice (NL: C186 and R197; Portugal: C175, R182; Luxembourg C181, R188) and the Czech Republic once (R198).

12 Non-coherent voting after common EU representation took place in the following instruments: (C181 \& R188), (C183 \& R191), (C187 \& R197) and (R198).
} 
relevance, and therefore performance, must take into account the institutional setting the EU is acting in.

\section{The effectiveness of EU common action}

For the EU to effectively upload its policy preferences into ILO technical standards, it must prioritise representation in the fifth stage of the policy-making process. From the empirical data presented, the EU is most active in occupational health and safety (OSH) and labour market regulation. This trend parallels the expansion of community competency after 1987 under Title XI of the Single European Act (Social Policy, Employment, Vocational Training and Youth) as detailed in Article 137. As I have argued elsewhere (Kissack 2009a), the acquis communautaire serves as a convenient foundation upon which to build EU representation, as both a common reference point for departure and a set of objectives to be internationalised. As a departure point it provides the Presidency with a minimal corpus of common interventions, while the rationales for uploading vary from ensuring compatibility between EU law and ILO standards, promoting best practice, or protecting the European social model by exporting similarly high standards. The EU is also not averse to threatening nonratification by its members if it does not see its preferences uploaded, albeit on the grounds of incompatibility between EU law and ILO conventions. In the past the EU has proven adept at uploading its preferences but it has come at a cost to the ILO. Correlating EU participation ${ }^{13}$ in drafting an instrument with the eventual number of ratifications it receives from all ILO members, a statistically significant inverse relationship is found, leading to the conclusion that EU interests are not always compatible with those of the ILO (Kissack 2009c). However, this observation is based on data stretching back to 1973, when EU common representation began. In the last two decades the EU has participated less, leading to the question of whether the EU is making less effort to influence the contents of instruments than it used to.

\footnotetext{
13 'Participation' is defined here as a function of the number of EU interventions performing one of five roles in the negotiating process and the total length of negotiations (Kissack 2008).
} 
Riddervold's highly insightful work on EU coordination in preparation for the Maritime Labour Convention (MLC) of 2006 dispels doubts that the EU is less concerned to incorporate its preferences into the final policy outcome (Riddervold 2008, 2009 - also see Tortell et al 2009). With direct access to preparatory meetings and the conference itself, she provides a convincing account of how EU member states entered the coordination process focused on national interests, minimising the costs of compliance to their economy and unsure of the value of a common EU position. Yet coordination resulted in Uturns on all three issues by those members previously suspicious of common representation. However, in the records of proceedings, the EU Presidency seldom spoke and it is difficult to reconcile so much preparatory work with so little evidence of influence. The answer is, quite literally, beyond the text. Informal working groups on specific questions and a 'Friends of the Presidency' minilateral core of key actors that included the EU, worked to resolve contentious issues in informal negotiations. Such techniques for reaching agreement in complex issues follow the 'active consensus' approach (Buzan 1981), helping bridge the nature stratification among ILO members seeking minimal standards and those seeking maximal standards. When institutional practices such as active consensus negotiations are used, the EU Presidency has the opportunity to participate in an exclusive club of powerful actors with a much greater capacity to influence final policy outcomes. However, whether the EU successes or not depends on its ability to persuade the other actors, and the EU's relative power among the group. In the case of the MLC, the convention allows ratifying states to withhold the principle of 'no more favourable treatment' to ships registered in countries that have not ratified the convention (Tortell et al 2009: 116), granting the EU considerable bargaining leverage thanks to its importance in global shipping. By contrast, when the same negotiation techniques were used in 1999 to draft the convention on the worse forms of child labour (C182), developing states achieved their goals and left EU states disappointed (Kissack 2010: 80-1). 


\section{Political case study}

\section{EU relevance: condemning labour standards violations}

EU involvement in the Committee on the Application of Standards (CAS) can be divided into two areas (for a detailed explanation see Orbie and Tortell 2009: 672-5). The first is the EU Presidency issuing statements on behalf of the EU (and aligned states) criticising labour standard violations, and the second is EU member states defending themselves against complaints. The latter happens surprisingly often; the UK was repeatedly included among the 25 annual review cases during 1990s for violating freedom of association, and in the last decade three EU member states have been summoned to explain CLS violations and another eight for other ILO standards. ${ }^{14}$ In every case, neither other EU member states nor the EU as a whole intervened in the discussion. It would seem reasonable to ask why integration has not yielded solidarity between EU member states when one is singled out for scrutiny, especially when the acquis communautaire tightly binds their labour laws. What prevent a greater display of solidarity are the established, informal norms aimed at minimising politicisation of the committee, and when governments may issue statements.

How does the EU perform when member states delegate to the Presidency the right to speak on their behalf? The first EU Presidency statement in the CAS was in 2000 on the subject of forced labour (C29) in Myanmar, undoubtedly the most serious and persistent violation of a core labour standard in the ILO's history, and one it has taken the most steps to alleviate (Maupain 2005). From that year onwards, the Presidency has issued a statement in every subsequent CAS, pointing to path dependency in the production and issuing of EU statements. There are other cases; freedom of association (C87) has been addresses six times vis-à-vis Belarus, five times vis-à-vis Colombia, and four times vis-à-vis Zimbabwe. Freedom of association in Myanmar, forced labour in

\footnotetext{
${ }^{14}$ Germany (2002) C29 (forced labour); UK (2006) C100 (equal pay) and (2007) C87 (freedom of association); Czech Republic (2008 and 2010) C111 (discrimination). Non core labour standards: Portugal (2003); the Netherlands, Poland and Slovenia (2005); Ireland (2006); Italy and Spain (2007); Sweden (2008) and Italy (2009).
} 
Sudan, and child labour in Uzbekistan have all been the subject of one EU statement. None exhibit the consistency found with C29 in Myanmar, so what explains this variation? There are two considerations. The first are institutional constraints imposed on the EU by the ILO. The EU can only issue a statement when it relates to a CAS case, and agenda setting power lies with workers and employers, making it reactive rather than proactive. The second is the relevance of the EU to its member states, and looking at a few cases individually highlights how the degree of unity, internal coordination and delegation to the Presidency are important variables.

The murder of trade unionists in Colombia constitutes a severe violation of freedom of association. The first complaint was made in 1998 and in 2000 the Governing Body appointed a Special Representative to liaise between the ILO and the Colombia government which yielded very little in the way of progress, hence its inclusion in the CAS from 2000-2005, and again in 2008-2009. Unlike the Myanmar case there was no history of CFSP common positions on Colombia. The Swedish Presidency secured an EU statement in 2001 based on a Nordic statement issued the previous year, but the following year the Spanish Presidency refused to issue one in 2002, despite the worsening situation in the country. Interviews with diplomats working in Geneva attributed this to Spain's historic ties with Latin America (Kissack 2007). The situation only changed with the election of the Socialist Party (PSOE) in March 2004, when the government became more critical of Colombia's poor human rights policy, evidenced by an EU Presidency statement on 30 June and the conclusions of the December Council meeting. ${ }^{15}$ In the ILO the ramification of this policy shift at the European level was a CAS statement on Colombia in 2004, and every year since when it has been on the agenda. In 2009, after the Czech Presidency issued an EU statement critical of Colombia, the Spanish government spoke individually in support of the progress made by the Colombian government (ILO 2009: 30). Despite the PSOE remaining in government, this example demonstrates that although long-

\footnotetext{
15 Presidency Statement on Colombia 30 June 2004 (EC-Bulletin 6/2004 1.6.21); Council conclusions on Colombia 13 December 2004 (EC-Bulletin 12/2004 1.6.142)
} 
standing national interests have re-emerged, they are no longer strong enough to prevent a common position being articulated. The degree of unity between EU member states on the relevance of common statements has increased over time in this case.

The case of Zimbabwe reveals a different trend. Smith (2006) provides a comprehensive overview of the EU actions starting in 2002 to apply pressure on the government of Robert Mugabe to improve its human rights and democracy record. Freedom of association of trade unionists is widely considered to be an important element of the democratic process, and Zimbabwe was included in the CAS list of 25 cases in 2002. Ireland introduced a common statement on Zimbabwe in 2004, which was followed up in 2005, 2006 and 2008 (after which Zimbabwe was dropped from the CAS). Why did the German Presidency fail to issue one in 2007? Historical precedents can provide a useful guide to why the EU acted in the way it did. The EU-Africa summit scheduled for Lisbon in December 2007 raised the question of whether President Mugabe should be allowed to attend given that he was subject to an EU-travel ban (which Portugal overlooked and allowed him to attend). ${ }^{16}$ Smith describes a similar situation in 2003 whether Mugabe's travel to Paris for a Franco-African summit on 19 February was the subject of debate in Council. 'The EU's sanctions [against Zimbabwe] were due to be renewed on 18 February, and France threatened to veto their renewal if the other member states did no allow Mugabe into France' (Smith 2006: 162). Given the apparent willingness of EU states to pursue national interests over and above EU commitments to human rights protection, the conspicuous absence of a Zimbabwe statement in the six months before the controversial summit is not surprising within the bigger picture of EU-Africa relations and the interests of certain member states in promoting them. The internal coordination of the EU, and the extent to which lowest common denominators remain highly important in determining the relevance of the EU, is evident in this case.

\footnotetext{
16 The ban was lifted at the request of African states. 'EU to break travel ban on Mugabe for Africa summit' http://euobserver.com/9/25230 (accessed 3/12/2010)
} 
Finally, the institution of the EU Presidency is an important variable to consider. In contrast to the Spanish example above, where the Presidency restricted the number of common statements made, the Luxembourg Presidency of 2005 doubled the number of statements from three (in 2004) to six. The reason given by EU diplomats was that the First Secretary of the Luxembourg mission in Geneva (Ms Jacqueline Ancel) had previously worked in the ILO department responsible for monitoring standards (Kissack 2007: 21). A number of diplomats were aware of this and questioned whether it influenced the decision of the Luxembourg Presidency to coordinate six statements. Two of those prepared, freedom of association in Myanmar and forced labour in Sudan, have never been the subject of EU common statements again, despite appearing repeatedly on the CAS agenda in subsequent years. Why do some presidencies succeed in establishing a practice of issuing statements and others do not? Clearly part of the answer lies in finding an EU consensus on the need to pursue a case. Moreover, the case must appear repeatedly on the CAS agenda, meaning that there must be a broad consensus in the ILO of its importance. However, there also needs to be an informal consensus among governments that they will choose to speak up; in the case of Sudan in 2005 the EU was the only non-African governmental voice heard; in the case of freedom of association in Myanmar (separate from the complaint about forced labour), only the EU and the US issued statements. When condemnation comes exclusively from rich, Western states, the risk arises that the issue is seen as overtly politicised. The scope for Presidency entrepreneurship is therefore demarcated by the wider norms and practices established within the CAS, demonstrating that institutional structures influence what the EU can do.

\section{EU effectiveness}

Upholding labour standards, promoting the decent work agenda, and ensuring consistency with CFSP common positions are the core EU goals directing involvement in the political domain, and the former two are shared by the vast 
majority of actors in the ILO. The combination of a harmony of interests (upholding labour standards), institutional rules (limiting case selection to workers and employers) and informal norms of behaviour (limiting governments statements to avoid politicisation) constitute the structural constrains on EU action by the ILO environment. The CAS uses dialogue and persuasion to apply gradual pressure to bring about compliance rather than antagonise violating states further. The working method of the CAS is well-suited to the political statements the EU is good at making, namely delicately worded and widely supported. The EU's capacity to be effective in the ILO's political domain, and therefore its performance generally, is the product of ILO institutions and EU institutions. Once again, we cannot explain EU performance in isolation from the institutional setting in which it is operating.

\section{Wider considerations: efficiency, resource allocation and the impact of the Lisbon Treaty}

Since the European Union is not a member of the ILO it does not make financial contributions to the regular budget of the organisation. However, between 20062010 it ranked second $(\$ 123 \mathrm{~m})$ behind the US $(\$ 218 \mathrm{~m})$ in terms of voluntary contributions supporting ILO technical cooperation programmes. ${ }^{17}$ The majority of this money ( $\$ 68 \mathrm{~m}$ ) was pledged in 2008 to be spent over a number of years and across a number of programmes, and the EU also provided $€ 1.7 \mathrm{~m}$ towards the 2006 International Maritime Conference (Tortell et al 2009: 119). Impressive as these numbers sound, when regular budget contributions factored into the equation the picture drastically changes. During the same five years (20062010 ), the US contributed $22 \%$ of the regular budget ( $\$ 85.5 \mathrm{~m}$ in 2011 ), making its total contribution to the ILO during this period approximately $\$ 650 \mathrm{~m}$ (ILO 2011). ${ }^{18}$ The Netherlands, ranked third in voluntary contributions at $\$ 91 \mathrm{~m}$, is roughly equal to the EU when its five annual contributions to the regular budget

17

http://www.ilo.org/public/english/bureau/pardev/download/development/donors/funding20 06-10.pdf (accessed 5 June 2011).

18 The ILO is committed to zero real growth in its regular budget, making 2011 figures broadly accurate indicators of contributions over the last five years (ILO 2008: §233). 
(\$7.2m in 2011) are added. Indeed, Germany, the UK, France each contributed more through their combined payments to the ILO than the EU, while Italy contributed approximately the same amount. ${ }^{19}$ Thus in terms of resource allocation, as is the case more generally in the UN system, the EU and its member states are, collectively, the largest donors to the ILO. In terms of efficacy, the most significant recent example is European Community funding for the 2006 conference drafting the MLC. The MLC is noteworthy for a number of reasons; it forms the fourth pillar in the 'international maritime regulatory regime' (Doumbia-Henry et al 2006 quoted in Tortell et al 2009: 114), it promotes the decent work, and it consolidates and updates around 60 existing ILO standards. Since the ILO was the only international organisation realistically capable of delivering a successful outcome, the EU was right to pursue its goals through the ILO.

What impact will the Lisbon Treaty make? Much attention has focused on Lady Ashton's position as High Representative of the Union for Foreign Affairs, the External Action Service, and the international legal personality of the EU. At the time of the 2010 ILC institutional arrangements had not been formally established, and it is too early to assess the 2011 conference. Nevertheless, a few general remarks can be made about technical and political domains. In the former, the Lisbon Treaty only changes the nameplate, because it is still a matter of external representation of Community competencies (ex Pillar One). Commission and EAS (Council) officials still assist the Presidency speaking for the EU, determined pragmatically according to the issue at hand. In the latter, the impact of the Lisbon Treaty will be greater, although exactly what the impact will be is unclear. What is most likely is that the EAS will be more closely involved in the drafting of EU statements in the CAS. On the one hand this will reduce the entrepreneurial opportunities of member state diplomats that was significant in the early years of coordination, while on the other hand the EAS could act as an

\footnotetext{
19 Germany: $\$ 31.1 \mathrm{~m}$ annual regular budget contribution (ARBC) and $\$ 13 \mathrm{~m}$ voluntary contribution (VC); UK: \$25.7m ARBC and \$48.8m VC; France \$23.8m ARBC and \$36m VC; Italy: $\$ 19.4 \mathrm{~m} \mathrm{ARBC}$ and $\$ 33 \mathrm{~m}$ VC.
} 
entrepreneur itself when cases arise congruent with existing CFSP common positions. Whether greater EAS oversight leads to more or less CAS statements in the future is unclear, but what is certain is that EAS officials must become well versed in the norms of CAS operation designed to limit politicisation if the EU is to maintain its influence

\section{Conclusion}

This article assesses EU performance in the ILO between 1992 and 2010 through the prisms of effectiveness and relevance and across technical and political policy domains. In the technical domain the primary goal of the EU is 'simply ensuring full legal consistency with EU legislation' (Tortell et al 2009: 118), although different justifications have been given and differing degrees of ultimate success enjoyed. The EU was relevant to its member states in $50 \%$ of technical standard committees, defined as coordinated representation that has an impact on the final policy output. This figure is marginally less than for the period 1973-1992 (the first year ECC coordination began), a surprising finding given an expectation of increased integration over time. Finally, cases of incoherent voting in the ILC plenary after common EU representation in drafting committees do not necessarily constitute a lack of relevance for the EU, but may be examples of strategic action balancing opposing domestic and international commitments. In the political domain, the EU was effective within the institutional parameters of the Committee on the Application of Standards. Without agenda setting power, and in pursuit of goals shared across the wider ILO membership, EU effectiveness is entwined with the effectiveness of the ILO itself. However, EU common statements are well suited to the modus operandi of the CAS, which prefers using dialogue and persuasion to promote compliance with labour standards. Analysis of performance hinges on the increased relevance of the EU Presidency for member states, in terms of speaking on behalf of the Union, prioritising common statements over national interests, and allowing entrepreneurial Presidencies to expand the scope of EU interests. 
ILO institutional structures shaped EU behaviour in both domains. In technical issues this was seen in member state prioritising cohesion in drafting committees over plenary sessions, in accordance with informal norms of behaviour widely shared by all ILO members. In the political domain the clearest example of institutional norms shaping EU behaviour was in determining whether the EU would speak in CAS. ILO-wide interest in avoiding politicisation of the committee determined which violations would be universally condemned. This established an expectation about when the EU should speak, as well as when it would not. The finding that the EU has focused on a small number of countries is as much influenced by ILO norms as path dependency within the EU. In summary, the EU has moulded its behaviour to fit the ILO institutional environment by adopting its norms. From the perspective of the EU, this is itself a manifestation of good performance. From the perspective of the ILO, an international organisation seeking to reinvent its role in the $21^{\text {st }}$ century, this is a also good news. If the ILO is to play an important role in global governance, it must be capable of curbing the influence of its strongest members. Somewhat counter-intuitively, curbing the performance of the EU is in its own self-interest, if doing so increases ILO performance too.

\section{References}

Alston, P. (2005) 'Labour Rights as Human Rights: The not so happy state of the art', in Alston, P. et al (eds.) Labour rights as human rights, Oxford: Oxford University Press, pp. 1-25.

Buzan, B. (1981) 'Negotiating by Consensus: Developments in Technique at the United Nations Conference on the Laws of the Sea' The American Journal of International Law, Vol. 75, No.2, pp. 324-348.

Cavicchiolo, L. (2002) 'The relations between the European Community and the International Labour Organisation' in Cannizzaro, E. (ed.) The European Union as an Actor in International Relations, The Hague: Kluwer Law International, pp. 261-269.

Delarue, R. (2006) 'ILO-EU Cooperation on Employment and Social Affairs' in Wouters, J., F. Hoffmeister \& T. Ruys (eds.) The United Nations and the European Union. An Ever Closer Partnership, The Hague: T.M.C. Asser Press, pp. 93-114. 
EC (1994) Proposal for a Council decision on the exercise of the Community's external competence at International Labour Conferences in cases falling within the joint competence of the Community and its Member States COM 942 Final $10 / 1 / 1994$.

EC (2001) Promoting Core Labour Standards and Improving Social Governance in the Context of Globalisation, COM (2001) 416 Final 18/7/2001.

EC (2004) The Social Dimension of Globalisation - the EU's policy contribution on extending the benefits to all, COM (2004) 383 Final 18/05/2004.

EC (2006) The EU contribution to the implementation of the decent work agenda in the world, COM (2006) 249 Final 24/06/2006.

EC (2008) Commission Staff Working Document: Report on the EU contribution of decent work in the world, SEC(2008) 2184

ECJ (1993) Opinion 2/91: Convention № 170 of the International Labour Organization concerning safety in the use of chemicals at work, 0J C109 19/04/1993.

EESC (1995) Own-Initiative Opinion on: Relations between the EU and the International Labour Organisation CES 46/95.

EESC (2007) Opinion of the European Economic and Social Committee on the EU contribution to the implementation of the decent work agenda in the world SOC $25017 / 01 / 2007$.

EU Council (2003) From CONUN to PSC: Consolidated Report on the Commission's Communication on 'The EU and the UN: the choice of multilateralism' (15080/03) 21/11/2003.

EU Council (2007) Brussels European Council: Presidency Conclusions 14 December 2007 (16616/1/07)

ILO (2008) Strategic Policy Framework 2010-2015 and preview of the Programme and Budget proposal for 2010-11 (GB.303/PFA/2), Geneva: International Labour Organisation.

ILO (2009) Report of the Committee on the Application of Standards (Part II), Geneva: International Labour Organisation.

ILO (2011) Programme and Budget for 2010-11 (GB.310/PFA/1/2), Geneva: International Labour Organisation.

Johnson, A. (2005) European welfare states and supranational governance of social policy, Basingstoke: Palgrave.

Kissack, R. (2007) Implementing EU Foreign Policy in the United Nations System: Mapping 'Virtual' and 'Real' Coordination in Geneva. Paper presented at International Studies Association Convention (ISA) Chicago. 
Kissack, R. (2008) 'EU Actorness in the International Labour Organisation: Comparing declaratory and voting cohesion’ Global Society, Vol. 22, No. 4, pp. 469-489.

Kissack, R. (2009a) 'How to lose friends and alienate people? The EU as a global social power' European Journal of Social Policy, Vol. 19, No.2, pp. 99-116.

Kissack, R. (2009b) 'When European Union Member State voting cohesion does not matter: Lessons learnt about majoritarian decision-making from the ILO' Studia Diplomatica, Vol. 62, No.1, pp. 55-73.

Kissack, R. (2009c) 'Writing a new normative standard? EU member states and the drafting and ratification of ILO labour standards' in Orbie, J. \& L. Tortell (eds.) The European Union's Role in the World and the Social Dimension of Globalisation, London: Routledge, pp. 98-112.

Kissack, R. (2010) Pursuing Effective Multilateralism: The European Union, International Organisations and the politics of decision making, London: Palgrave.

Maupain, F. (2005) 'Is the ILO Effective in Upholding Workers' Rights?:

Reflections on the Myanmar Experience', in Alston, P. et al (eds.) Labour rights as human rights, Oxford: Oxford University Press, pp. 85-142.

Nedergaard, P. (2009) 'The European Union at the ILO's International Labour Conferences: A 'double' principal-agent analysis' in K.E. Jørgensen (ed.) The European Union and International Organizations, London: Routledge.

Novitz, T. (2005) 'The European Union and international labour standards: the dynamics of dialogue between the EU and the ILO', in Alston, P. et al (eds.) Labour rights as human rights, Oxford: Oxford University Press, pp. 214-241.

Novitz, T. (2008) 'Legal Power and Normative Sources in the Field of Social Policy: Normative Power Europe at Work?' in Orbie, J. (ed.) Europe's Global Role: External Politics of the European Union, Farnham: Ashgate, pp. 139-158.

Novitz, T. (2009) 'In search of a coherent social policy: EU import and export of ILO labour standards?' in Orbie, J. \& Tortell, L. (eds.) The European Union's Role in the World and the Social Dimension of Globalisation, London: Routledge, pp. 2744.

Orbie, J. \& O. Babarinde (2008) 'The social dimension of globalization and EU development policy: Promoting core labour standards and corporate social responsibility', Journal of European Integration, Vol. 30, No. 2, pp. 459-477.

Orbie, J. \& L. Tortell (2009a) 'From the social clause to the social dimension of globalization' in Orbie, J. \& L. Tortell (eds.) The European Union's Role in the World and the Social Dimension of Globalisation. London: Routledge, pp. 1-26.

Orbie, J. \& L. Tortell (2009b) 'The New GSP+ Beneficiaries: Ticking the Box or Truly Consistent with ILO Findings?' European Foreign Affairs Review Vol. 14, No. 3, pp. 663-681. 
Riddervold, M. (2008) Interests or Principles? EU Foreign Policy in the ILO? RECON Online Working Paper 2008/09, ARENA, Norway.

Riddervold, M. (2009) Why do they agree? An empirical analysis of EU coordination in the ILO Paper Presented at the European Union Studies Association Biennial Convention, Los Angeles.

Smith, K.E. (2006) 'The limits of proactive cosmopolitanism' in O. Elgstrom and M. Smith (eds) The European Union's Roles in International Politics: Concepts and Analysis, Abingdon: Routledge pp. 155-171.

Tortell, L., R. Delarue \& J. Kenner (2009) 'The EU and the ILO Maritime Labour Convention' in Orbie, J. \& L. Tortell (eds.) The European Union's Role in the World and the Social Dimension of Globalisation, London: Routledge, pp. 113-130. 